Kuningan relatif datar dengan variasi berbukit-bukit di bagian barat dan selatan, selain itu Kabupaten Kuningan memiliki suhu yang sejuk. Keadaan topografi ini membuat Kabupaten Kuningan memiliki berpotensi mengembangkan sektor pariwisata dan sudah memiliki beberapa objek wisata yang cukup terkenal seperti pemandian air panas Sangkanhurip, Cibulan Mata air (Taman Nasional Gunung Ciremai), Gedung perundingan Linggarjati, Curug Sidomba, dan pendakian Gunung Ciremai (jalur Linggarjati dan palutungan).

Menurut hasil Survey Sosial Ekonomi Daerah (Suseda) pada tahun 2010, diperkirakan sekitar $25 \%$ penduduk Kuningan bersifat comuter, banyak yang bermigrasi ke kota-kota besar. Hal ini menyebabakan Kuningan mendapat banyak kunjungan pada saat liburan atau hari-hari libur perayaan

Banyaknya objek wisata di Kuningan juga menyebabakan Kabupaten Kuningan di kunjungi wisatawan daerah sekitar seperti Majalengka, Brebes, Cirebon sampai Indramayu. Dikarenakan adanya kunjungan-kunjungan wisatawan membuat permintaan terhadap oleh-oleh khas Kuningan khususnya Tape melonjak naik. Menurut hasil observasi pada bulan februari 2014 pada perusahaan pembuat tape dengan merk dagang Rasa Manis mengatakan bahwa produksi pada saat musim liburan atau musim libur lebaran menjadi 5 kali lipat dari pada produksi hari biasa. Tape khas Kuningan adalah tape yang berwarna hijau, terbuat dari ketan hijau yang difermentasikan dan di beri air daun katuk sebagai pewarnanya. Menurut distributor oleh-oleh khas Kuningan permintaan tape pada musim libur lebaran bukan hanya tape hijau yang dibungkus daun jambu, permintaan terhadap tape hitam pun meningkat. Penggemar tape kuningan ini sudah tersebar di seluruh penjuru pulau jawa bahkan ada yang sampai ke luar jawa, namun sebagian besar perusahaan tape di Kabupaten Kuningan hanya memproduksi Tape ketan yang dibungkus daun jambu. Produksi untuk tape ketan hitam hanya berdasarkan pesanan saja padahal penggemar tape ketan hitam pun cukup banyak

Tapai atau biasa disebut Tape merupakan makanan khas Jawa Barat yang bahan dasarnya difermentasikan. Bahan dasar yang dipakai untuk tape biasanya singkong beras ketan putih dan beras ketan hitam. Tape singkong dapat dijumpai di daerah Bandung ataupun daerah sekitar Bandung, sedangkan tape ketan putih yang dibungkus daun jambu banyak terdapat dan sekaligus makanan khas dari Kabupaten Kuningan, tetapi untuk Tape ketan hitam sudah sangat jarang ditemukan baik di daerah Bandung ataupun Kuningan. Sebagian besar penikmat tape ketan hitam maupun tape ketan kuningan mengeluhkan masa simpan tape yang sebentar sehingga tidak bisa disimpan untuk jangka waktu yang lama. Agar penikmat tape bisa menyimpan dan mengkonsumsi tape lebih lama maka diolahlah tape menjadi suatu kudapan yang memiliki daya simpan lebih lama. Salah satu pengawetan makanan dengan cara alami yaitu pengawetan dengan konsentrasi gula seperti selai.

Selai atau jam adalah makanan yang terbuat dari buah yang dihancurkan dan ditambah dengan gula, bertekstur setengah padat atau kental. Selai merupakan makanan pendamping yang tidak bisa disajikan sendiri sehingga selai dapat dijadikan sebagai pendamping maupun bahan tambahan pada produk makanan lain. Selai banyak digunakan untuk olesan roti maupun isian roti, cake, donat, cookies dan makanan lainnya. 
Mengadopsi teori pembuatan selai buah, penulis terarik untuk mengaplikasikan tape ketan menjadi Selai.

\section{TUJUAN PENELITIAN}

1. Untuk mengetahui alur pembuatan Selai tape ketan hitam dan Selai tape ketan Kuningan.

2. Untuk mengetahui formula resep Selai tape ketan hitam dan Selai tape ketan Kuningan.

3. Untuk mengetahui daya terima konsumen tape ketan terhadap Selai tape ketan hitam dan selai tape ketan Kuningan.

\section{METODE PENELITIAN}

Metode penelitian yang digunakan terdiri dari 3 tahap yaitu :

1. Mengidentifikasi alat dan bahan yang digunakan, melakukan percobaan pada standar resep sehingga di dapatkan standar resep yang diinginkan. Metode analisis data menggunakan analisis deskriptif untuk mendeskripsikan tahap-tahap pada proses pengolahan Selai.

2. Untuk mengidentifikasi formula resep, melakukan uji organoleptik dan uji hedonik. Proses pengujian dimulai dengan pembuatan produk Selai tape ketan hitam dan Selai tape ketan Kuningan dengan masing-masing tiga perlakuan yang berbeda. Produk kemudian diujikan kepada 15 orang panelis ahli dengan cara membagikan produk dengan masing-masing tiga perlakuan beserta kuisioner. Kriteria pengujian organoleptik dan pengujian hedonik meliputi rasa, aroma, warna, tekstur dan penampilan. Hasil dari pengujian organoleptik dianalisis dengan menggunakan analisis ANOVA, LSD dan Turkey's $b$ sedangkan hasil dari pengujian hedonik di analisis dengan mengunakan analisis independent t-test sample. Produk terpilih kemudian diamati daya tahan simpannya dan dianalisis gizi berdasarkan DKBM.

3. Tahapan pada pengujian daya terima konsumen yaitu memberikan produk terpilih kepada 100 orang konsumen beserta kuisioner. Kriteria penilaiannya yaitu meliputi kualitas produk (rasa, aroma, warna, tekstur dan penampilan), Penilaian terhadap produk (rasa, aroma, warna, tekstur dan penampilan), dan penilaian kesukaan pada masing-masing produk (rasa, aroma, warna, tekstur dan penampilan). Hasil dari uji penerimaan konsumen dianalisis dengan menggunakan analisis korelasi dan analisis regresi sederhana. Tahap terakhir yaitu pembuatan label untuk kemasan.

\section{POPULASI}

Dalam penelitian ini tidak menggunakan sampling akan tetapi hanya menggunakan populasi. Populasi pada tahap uji organoleptik atau uji hedonik sebanyak 15 orang yang terdiri dari panelis ahli dalam bidang makanan sedangkan pada tahap uji daya terima konsumen menggunakan populasi sebanyak 100 orang panelis terlatih yang terdiri dari konsumen tape ketan kuningan. 


\section{TEKNIK ANALISIS DATA}

\section{Perhitungan Analisis Varian}

$$
\begin{aligned}
& \mathrm{FK}=\frac{\text { Total }^{2}}{\text { Jumlah kelompok } \times \text { Jumlah perlakuan }} \\
& \mathrm{JK} . \mathrm{S}=\left(\frac{\text { Jumlah kuadrat total tiap sampel }}{\text { Jumlah panelis }}\right)-F K \\
& \mathrm{JK} . \mathrm{P}=\left(\frac{\text { Jumlah kuadrat total tiap panelis }}{\text { Jumlah sampel }}\right)-F K \\
& \mathrm{JK} . \mathrm{T}=\text { Total jumlah kuadrat }-F K \\
& \text { JK Error }=\text { JK.T }-\mathrm{JK} . \mathrm{S}-\mathrm{JK} . \mathrm{P}
\end{aligned}
$$

Hasil analisis varian yang telah diperoleh kemudian disusun seperti pada Tabel

Tabel 3.4 Analysis of Variance (ANOVA)

\begin{tabular}{|c|c|c|c|c|}
\hline $\begin{array}{c}\text { Sumber } \\
\text { varian/ } \\
\text { ragam }\end{array}$ & df & JK & JKR & $\begin{array}{c}\mathrm{F}_{\text {tabel }} \\
(5 \%)\end{array}$ \\
\hline $\begin{array}{c}\text { Sampel } \\
(\mathrm{S})\end{array}$ & $\mathrm{n}_{\text {sampel }}-1$ & JK (S) & $\frac{J K \text { Sampel }}{\text { df Sampel }}$ & \\
\hline $\begin{array}{c}\text { Panelis } \\
(\mathrm{P})\end{array}$ & $\mathrm{n}_{\text {panelis }}-1$ & JK (P) & $\frac{J K \text { Panelis }}{\text { df Panelis }}$ & \\
\hline $\begin{array}{c}\text { Error } \\
(\mathrm{E})\end{array}$ & $\begin{array}{c}\left(\begin{array}{c}\mathrm{n}_{\text {sampel }}- \\
\left(\mathrm{n}_{\text {panelis }}\right.\end{array}\right. \\
-1)\end{array}$ & JK (E) & $\frac{J K \text { Error }}{\text { df Error }}$ & \\
\hline Total & & & & \\
\hline
\end{tabular}

Sumber : Setyaningsih dkk,2010,hlm. 47

Keterangan :

df $=$ Derajat bebas

$\mathrm{JKR}=$ Jumlah kuadrat rata-rata

$\mathrm{F}=\frac{J K R}{J K R \text { Error }}$

Hasil yang telah didapat dari Analysis of Variance (ANOVA) selanjutnya dilakukan uji Least Siignificant Difference (LSD) dengan selang kepercayaan 95\% untuk mengetahui pengaruh antar perlakuan. Tahapan uji LSD akan diuraikan sebagai berikut :

1. Mencari Standar error dengan rumus

$$
\text { Standar error }=\sqrt{\frac{J K R}{J \text { Jumlah Panelis }}}
$$

2. Mencari LSD pada tabel Significant studenized rang at the $5 \%$ level. Untuk nilai pembanding adalah:

Standar error $x$ LSD

3. Nilai rata-rata hasil perhitungan diurutkan dari mulai yang terbesar sampai yang terkecil kemudian dibandingkan dengan nilai pembanding.

Untuk membandingkan dua sampel setiap produk eksperimen dengan produk terkontrol maka dilakukan uji hedonik dua sampel t-test. Dengan perhitungan : 
Mencari nilai standar :

$$
\begin{aligned}
& \mathrm{S}=\sqrt{\frac{\frac{\sum d^{2}-\left(\sum d\right)^{2}}{n}}{n-1}} \\
& \text { Mencari } \mathrm{t} \text { hitung }: \mathrm{t}=\frac{a}{\frac{s}{\sqrt{n}}}
\end{aligned}
$$

Keterangan :

$\mathrm{S}=$ Nilai standar

$\mathrm{d}=$ nilai perbedaan

$\mathrm{n}=$ jumlah panelis

$\mathrm{a}=$ Rata-rata jumlah pembedaan $(\mathrm{d})$

$\mathrm{s}=$ akar dari nilai standar

Setelah di dapat nilai $t_{\text {hitung }}$ kemudian dibandingkan dengan $t_{\text {tabel }}$. Nilai $t_{\text {tabel }}$ dicari pada tabel distibusi - $t$ dengan $\alpha=5 \%$ sehingga dapat ditarik kesimpulan apabila nilai $\mathrm{t}_{\text {hitung }}$ lebih lebih besar dari $\mathrm{t}_{\text {tabel }}$ maka antar sampel berbeda nyata.

\section{Koefisien Korelasi}

$$
r_{x y}=\frac{\sum x y}{\sqrt{\sum x^{2} y^{2}}}
$$

Dimana : $\mathrm{r}_{\mathrm{xy}}=$ korelasi antar variabel $\mathrm{x}$ dengan $\mathrm{y}$

$$
\begin{array}{ll}
\mathrm{x} & =\left(\mathrm{x}_{\mathrm{i}}-\overline{\mathrm{x}}\right) \\
\mathrm{y} & =\left(\mathrm{y}_{\mathrm{i}}-\overline{\mathrm{y}}\right)
\end{array}
$$

\section{Koefisien determinasi}

$\mathrm{KD}=(\mathrm{r})^{2} \times 100 \%$

\section{Analisis Gizi DKBM}

Analisis data yang digunakan dengan acuan DKBM, dengan standar AKG 2000Kkal. Langkah langkah dalam analisis gizi produk yaitu sebagai berikut :

1. Perhitungan nilai gizi karbohidrat, lemak dan protein dalam $100 \mathrm{gr}$.

2. Perhitungan nilai gizi karbohidrat, lemak dan protein pada ukuran penyajian.

3. Perhitungan nilai gizi kalori keseluruhan makro produk, dengan standar konfersi :

Karbohidrat $=$ Kandungan gizi $\mathrm{x} 4$

Lemak = Kandungan gizi $\mathrm{x} 9$

Protein = Kandungan gizi $\mathrm{x} 4$

4. Perhitungan $\mathrm{AKG}$ produk dengan menggunakan rumus :

$\frac{\text { kkal bahan }}{\text { standar kkal gizi makro }} \times 100 \%$

5. Pembuatan label AKG per kemasan. 


\section{HASIL PEMBAHASAN}

\section{Alur pembuatan Selai tape ketan}

Tape ketan yang dipakai untuk bahan percobaan adalah tape ketan hitam dan tape ketan kuningan, tape tersebut merupakan hasil proses fermentasi selama 5 hari. Penggunaan tape dengan proses fermentasi yang lama bertujuan agar tape memiliki aroma yang lebih kuat dan rasa yang lebih manis.

Proses pembuatan Selai tape ketan hitam dan Selai tape ketan kuningan dimulai dengan membuat tape ketan hitam dengan proses fermentasi selama 5 hari, lebih lama dari standart yang fermentasi yang biasa dibuat. Fermentasi yang lebih lama dilakukan dengan tujuan agar tape sangat matang, berair banyak, aromanya menjadi tajam dan rasa menjadi lebih manis.

\section{Formula pada resep Selai tape ketan}

Standar resep yang telah dipilih dalam penelitian ini akan diuraikan sebagai berikut :

Selai tape ketan hitam

- 100 g tape ketan hitam

- 30 g gula pasir

- 0,5 g gelatine powder

- $2 \mathrm{ml}$ air jeruk nipis

- Garam secukupnya

Selai tape ketan hijau

- $100 \mathrm{~g}$ tape ketan kuningan

- 20 g gula pasir

- 0,5 gelatine powder

- $2 \mathrm{ml}$ air jeruk nipis

- Garam secukupnya

Standar resep yang didapat berdasarkan uji organoleptik panelis ahli atas 3 perlakuan berbeda dengan lima karakteristik yaitu rasa, aroma, warna, tekstur dan penampilan.

\section{Hasil Uji Organoleptik panelis ahli}

Tahap uji hedonik antara Selai tape ketan hitam dan Selai tape ketan kuningan dari karakteristik rasa, aroma, warna, tekstur dan penampilan, panelis lebih menyukai produk Selai tape ketan hitam dibanding Selai Tape ketan kuningan berdasarkan uji Independent t-test sampel dengan selang kepercayaan 95\% menyatakan bahwa produk A tidak berbeda nyata dengan produk B karena selisih nilai $\mathrm{t}_{\text {hitung }}<\mathrm{t}_{\text {tabel }}$ dan nilai probabilitas $>0,005$.

\section{Hasil Uji Hedonik penelis ahli}

Uji organoleptik dilakukan berdasarkan lima kriteria (rasa, aroma, warna, tekstur dan penampilan). Dari kelima karakteristik tersebut panelis lebih menyukai Selai tape ketan hitam berkode $\mathrm{STKM}_{3}$ dengan perbandingan 10:3 sedangkan untuk Selai tape ketan kuningan panelis lebih menyukai produk berkode $S T K U_{1}$ dengan perbandingan $10: 1$ 


\section{Harga pokok penjualan Selai tape ketan}

Berdasarkan perhitungan food cost didapatkan harga jual produk Selai tape ketan hitam dan Selai tape ketan kuningan sebesar Rp. 20.000,- dengan mengambil profit sebesar $40 \%$.

\section{Uji Daya tahan simpan}

Hasil pengamatan selama 18 hari pada suhu ruang masing-masing produk dapat bertahan \pm 28 hari pada suhu ruang, apabila disimpan pada lemari pendingin dapat bertahan lebih lama.

\section{Analisis gizi berdasarkan DKBM}

Hasil perhitungan gizi berdasarkan dkbm di dapat kandungan energi pada produk Selai tape ketan hitam per $250 \mathrm{~g}$ sebesar 1425,2 kal, Protein sebesar 25,4g, lemak sebesar 2,3g, Karbohidrat sebesar 190,2g, kandungan mineral sebesar 123,7g dan vitamin sebesar 5,9g. Sedangkan hasil perhitungan gizi berdasarkan dkbm di dapat kandungan energi pada produk Selai tape ketan kuningan per 250g sebesar 1416,2 kal, Protein sebesar 3,2g, lemak sebesar 3,8g, Karbohidrat sebesar 190,2g, fosfor 716,2g, kalsium 363,4g, besi 8,8. Vit.A 15555g, Vit.B1 0,4 dan Vit.c 363.

\section{Uji Daya Terima Konsumen \\ Uji Organoleptik konsumen}

Selai tape ketan dilihat dari parameter rasa jumlah terbanyak sebanyak 63 orang menjawab sangat enak untuk produk Selai tape ketan hitam dan 62 orang menjawab enak untuk produk Selai tape ketan kuningan.

Parameter aroma jumlah terbanyak untuk Selai tape ketan hitam dan Selai tape ketan kuningan sebanyak 40 dan 45 orang menjawab cukup khas.

Parameter warna jumlah terbanyak sebesar 59 orang menjawab sangat menarik untuk warna pada Selai tape ketan hitam dan sebanyak 42 orang menjawab menarik untuk warna Selai tape ketan kuningan.

Parameter tekstur jumlah terbanyak untuk Selai tape ketan hitam dan Selai tape ketan hijau sebanyak 48 dan 42 orang menjawab cukup lembut.

Parameter penampilan jumlah terbanyak untuk Selai tape ketan hitam dan Selai tape ketan kuningan sebanyak 48 dan 42 orang menjawab cukup menarik.

\section{Uji Hedonik Konsumen}

Hasil dari uji hedonik antara produk Selai tape ketan hitam dan selai tape ketan kuningan yaitu konsumen lebih menyukai produk Selai tape ketan hitam daibanding Selai tape ketan kuningan. Perbandingan nilai kesukaan Selai tape ketan hitam dan Selai tape ketan kuningan dari 5 karakteristik (rasa, aroma, warna, tekstur, penampilan) berdasarkan uji Independent t-test sampel dengan selang kepercayaan 95\% menyatakan bahwa produk A tidak berbeda nyata dengan produk B karena selisih nilai $\mathrm{t}_{\text {hitung }}<\mathrm{t}_{\text {tabel }}$ dan nilai probabilitas $>0,005$. 


\section{Analisis daya terima konsumen pada kualitas produk}

Koefisien korelasi Spearman pada produk Selai tape ketan hitam sebesar 0,557 dengan Sig (2-tailed) $0,000<$ dari 0.01. pada produk Selai tape ketan kuningan sebesar 0,458 dengan Sig (2-tailed) 0,000 < 0,01. Dapat disimpulkan bahwa ada hubungan yang signifikan antara kualitas produk dan daya terima konsumen pada masing-masing produk.

Hubungan antara kualitas produk dan Daya terima konsumen untuk produk Selai tape ketan hitam adalah kuat positif, yaitu $\mathrm{r}=0,716$ dengan koefisien determinasi $51,3 \%$. Hubungan antara kualitas produk dan Daya terima konsumen untuk produk Selai tape ketan kuningan adalah sedang positif, yaitu $r=0,0553$ dengan koefisien determinasi $30,6 \%$.

Hasil dari uji $\mathrm{F}$ produk Selai tape ketan hitam adalah nilai $\mathrm{F}_{\text {hitung }}=103,048>\mathrm{F}_{\text {tabel }}$ $=3,09$ dengan selang kepercayaan $95 \%$. Hasil dari uji $\mathrm{F}$ produk Selai tape ketan hitam adalah nilai $\mathrm{F}_{\text {hitung }}=43,163>\mathrm{F}_{\text {tabel }}=3,09$ dengan selang kepercayaan $95 \%$. Dapat disimpulkan bahwa kualitas produk secara simultan memiliki pengaruh signifikan terhadap daya terima konsumen.

\section{SIMPULAN}

1. Bahan percobaan yang dipakai adalah Tape ketan hitan dan Tape ketan kuningan hasil proses fermentasi selama 5 hari. Standar resep pembuatan Selai tape ketan hitam yaitu $100 \mathrm{~g}$ tape ketan hitam, $30 \mathrm{~g}$ gula pasir, $0,5 \mathrm{~g}$ gelatine powder, $2 \mathrm{ml}$ air jeruk nipis, Garam secukupnya, sedangkan Selai tape ketan hijau yaitu $100 \mathrm{~g}$ tape ketan kuningan $10 \mathrm{~g}$ gula pasir, 0,5 gelatine powder, $2 \mathrm{ml}$ air jeruk nipis dan garam secukupya.

2. Konsentrasi perbandingan dengan nilai tertinggi untuk produk Selai tape ketan hitam adalah $\mathrm{STKM}_{3}$ dengan perbandingan 10:3 sedangkan untuk produk Selai tape ketan kuningan adalah STKU $\mathrm{U}_{1}$ dengan perbandingan 10:1. Komposisi dengan nilai tertinggi disimpulkan dari hasil uji organoleptik panelis ahli.

3. Hasil dari hedonik antara produk Selai tape ketan hitam dan Selai tape ketan kuningan adalah panelis lebih menyukai produk selai tape ketan hitam dari pada selai tape ketan kuningan.

4. Daya tahan pada produk selai tape ketan hitam dan Selai tape ketan kuningan sekitar \pm 28 hari pada suhu ruang.

5. Kandungan gizi dalam Selai tape ketan hitam dan Selai tape ketan kuningan hampir sama namun pada produk mineral dan vitamin pada produk Selai tape ketan kuningan lebih unggul tetapi untuk nilai kalorinya lebih unggul Selai tape ketan hitam.

6. Hasil penelitian yang dilakukan menyatakan produk Selai tape ketan hitam dan Selai tape ketan kuningan diterima dan signifikan dengan nilai skala 3-4 atau antara netral dan suka. Pengujian daya terima konsumen dilakukan kepada 100 orang panelis konsumen dengan lima karakteristik yaitu rasa, aroma, warna, tekstur dan penampilan. Pengujian pada produk dinyatakan diterima dengan skala 4-5 atau suka. 
7. Berdasarkan uji hedonik atau uji kesukaan antara Selai tape ketan hitam dengan Selai tape ketan kuningan konsumen lebih menyukai produk Selai tape ketan hitam pada semua karakteristik (rasa, aroma, warna, tekstur dan penampilan)

8. Kekuatan hubungan antara Kualitas produk dan Daya terima konsumen adalah sedang positif. Kontribusi yang disumbangkan kualitas produk Selai tape ketan hitam terhadap daya terima konsumen sebesar $51,3 \%$ sedangkan Kontribusi yang disumbangkan kualitas produk Selai tape ketan hitam terhadap daya terima konsumen sebesar 30,6\%. Berdasarkan pengujian signifikasi menggunakan uji $\mathrm{F}$ disimpulkan kualitas produk secara simultan memiliki pengaruh signifikan terhadap daya terima konsumen pada produk selai tape ketan hitam dan Selai tape ketan kuningan.

\section{DAFTAR PUSTAKA}

Buckle, K. A. Dkk. (1987). Ilmu pangan. Jakarta : UI-Press

Desrosier, N. W. (2008). Teknologi Pengawetan Pangan. Jakarta : UI-Press

Margaretha F. S. dan Edwin J. (2012). Analisa Pengaruh Food Quality dan Brand

Image terhadap Keputusan Pembelian Roti Kecik Toko Roti Ganep's di Kota

Solo. Jurnal Manajemen Pemasaran Vol.1, No.1.

Herudiyanto, M. S. (2008). Pengantar Teknologi Pengolahan Pangan. Bandung : Widya Padjajaran

Maryani, L dan Muliani, R. (2010) Epidemiologi kesehatan Pendekatan Penelitian. Yogyakarta : Graha Ilmu

Setyaningsih, D., Apriyanto, A., dan Sari, M. P. (2010). Analisis Sensori untuk Industri Pangan dan Argo. Bogor: IPB press

Suwantoro, G. (2004). Dasar-dasar Pariwisata. Yogyakarta : ANDI

Tjahjadi, C. (2008). Teknologi Pengolahan Sayur dan Buah Volume 2. Jakarta : Widya Padjajaran 